Article

\title{
Transformative Urban Living Labs: Towards a Circular Economy in Amsterdam and Turin
}

\author{
Federico Cuomo ${ }^{1, * \mathbb{C}}$, Stefania Ravazzi ${ }^{1}$, Federico Savini ${ }^{2}$ and Luca Bertolini ${ }^{2}$ \\ 1 Department of Cultures, Politics and Society, University of Turin, Lungo Dora Siena, 100 A, 10153 Torino, \\ Italy; stefania.ravazzi@unito.it \\ 2 Department of Human Geography, Planning and International Development, University of Amsterdam. \\ Nieuwe Acthtergracht 166, 1018 Amsterdam, The Netherlands; f.savini@uva.nl (F.S.); 1.bertolini@uva.nl (L.B.) \\ * Correspondence: federico.cuomo@unito.it; Tel.: +39-33-8834-5082
}

Received: 6 August 2020; Accepted: 15 September 2020; Published: 16 September 2020

\begin{abstract}
The circular economy is becoming a field of experimentation to trigger site-specific laboratories oriented towards connecting material flows and citizens' practices. Despite their wide use, a critical perspective of the transformative paths of these Urban Living Labs (ULLs) is still missing. This paper compares the paths followed by two such experiments, one in Amsterdam (The Netherlands) and the other in Turin (Italy). To this end, we build an analytical framework that targets three dimensions: unconventionality, autonomy, and systemic impact on policies. We conclude that ULLs can take very different transformation paths over time due to a wide range of enablers and barriers. In Amsterdam there has been an assimilation in the neighbourhood as well as a transformative effect on an urban scale; while the case of Turin has turned out to be potentially transformative but also at risk of marginalization.
\end{abstract}

Keywords: urban experimentations; urban living labs; circular economy; Amsterdam; Turin

\section{Introduction}

Cities are increasingly seen as sites that are capable of determining the future of our planet [1]. On the one hand, urban areas continue to depend on the linear economy of "take make dispose", based on a massive consumption of energy flows and the lack of waste recovery, which has led them to produce $50 \%$ of the world's waste and $80 \%$ of the world's pollutant gases [2]. On the other, cities have turned out to be creative and inspiring contexts that embrace the paradigm of the circular economy (CE from now onwards), focused on the reuse of products, the reduction of environmental impacts, and the recyclability of materials [3].

In the recent literature, a debate has been sparked about the capacity of urban experiments to be leverage-points, namely to produce transformations that can actually address urban development towards sustainability goals and foster the transition from linear economy to circular economy $[4,5]$.

Transformation through experimentation implies that current standard socio-technical configurations are de-institutionalized and new ones are developed, shared, and disseminated to actually propose an alternative model of development [6]. From this perspective, urban experiments should be able to generate moments in which classic means of governance are laid bare to contestation and open opportunities for the construction of innovative policies $[7,8]$.

Among urban experiments, Urban Living Labs (ULLs) are considered as processes and arenas that can be used to set up spaces to explore, examine, experiment, test, and evaluate creative ideas and innovative solutions in complex and everyday contexts [9]. ULLs are commonly based on flexible partnerships of public actors, companies, universities, and citizens aimed at increasing quality of life at a city scale [10]. The public actors in ULLs can take on the roles of promoters, enablers, 
and partners of the process of learning how to face societal problems or improve sustainable and circular policies [11,12]. ULLs are created to share knowledge in real-life contexts and catalyse effective political, technical, and economic changes by activating co-production and learning processes among urban stakeholders $[13,14]$. Even though ULLs are seen as "protected spaces" for alternative socio-technical configurations, these labs are neither a politically neutral activity nor a necessarily transformative one [15]. Research on sustainability transition has indeed questioned the impact of the method of "laboratory" on the historical and socio-ecological specificities of place [16,17]. Despite the growth of interest in ULLs, there is still a lack of empirical studies to help explain whether ULLs effectively preserve or dissipate their transformative potential $[18,19]$.

This paper attempts to contribute to this debate through an in-depth analysis of two ULLs in two circular economy transition contexts in order to detect whether they have generated specific patterns of transformation. The two ULLs have been taking place in Amsterdam (Buiksloterham Living Lab, BSH) and Turin (Living Lab on Sharing and Circular Economy (LLSC), together with other reuse initiatives, sharing services and material recycling. These two ULLs have been chosen applying the most different system design method: despite their common target they present significant differences. This allows to strengthen the research findings in case the same patterns of transformations are identified.

The article is structured as follows. After the introduction of the analytical framework chosen to analyse the performance and long-term effects of ULLs and the description of the methodology (Section 2), an overview of the contexts in which Amsterdam and Turin's CE labs take place is presented (Section 3), the legacy of the two ULLs is traced across three transformation dimensions (unconventionality, autonomy, and systemic impact on urban policies: Sections 4 and 5), and an attempt is made to compare and discuss the two trajectories (Section 6); finally, conclusions are drawn (Section 7).

\section{Research Design}

\subsection{Analytical Framework. Problematizing the Trajectories of Experiments}

Although urban experiments are emerging everywhere in cities, only a few of them turn into agents that can produce transformation [20]. A complex and nebulous set of institutional arrangements, governance dynamics, and place-based specifics might affect their paths [21]. These flexible conditions have revealed how urban experimentation cannot be considered as a singular phenomenon that can be easily understood using a unique model of interpretation [22].

In order to shed light and categorize the impacts produced by urban experiments, Savini and Bertolini [23] identified four possible ideal-typical trajectories. First, some urban experiments, especially those which consist of initiatives proposed by citizens and grassroots associations, may not be recognized by institutions and may be stopped at the taking-off phase, thus leading to the "death" of such an experiment. Another possible trajectory is "marginalization", which occurs when urban experiments are recognized by public actors but are not considered feasible or respectable for long-term policies. The third possible way is "assimilation", which distinguishes projects that are proposed and defined as experimental by public actors, even though they do not propose any real changes. These become embedded in the narrative of urban governance and integrated in local policy agendas with the aim of fulfilling the main economic stakes of consolidated coalitions, at the cost of their transformative potentials [24]. The last trajectory leads to an effective transformation: urban experiments challenge the regulations and management of spaces by promoting an alternative and unusual model of environmental and social policy, which eventually diffuses on an urban scale. Although this last trajectory is often, at least in rhetoric, pursued, it rarely materializes.

From a similar viewpoint, scholars have highlighted how each of the aforementioned pathways might specifically characterize ULLs. Even though ULLs might achieve effective transformation, they actually risk being stopped, marginalized, or assimilated [25]. ULLs could be handled and labelled by local institutions as experimental policies and become legitimacy practices for the most influential 
public-private coalitions [26]. The re-proposition of conventional public-private partnerships risks circumventing the transformative intent of ULLs and thus strengthening the ruling urban governance structures $[27,28]$. According to some recent studies, limits and risks are also apparent in BSH and LLSC $[29,30]$.

However, the two ULLs have not yet been problematized and their trajectories largely continue to be unstudied. With this purpose in mind, looking at the literature on urban experiments and ULLs, by means of a content analysis, we have built an analytical grid. This preliminary work has been based on a thorough review of the literature in the field of urban and governance studies, with a specific attention on written material containing keywords "urban experimentation", "urban living labs", and "circular economy." This early phase has led us to collect an extensive amount of scientific materials of scientific papers, books, and institutional reports (mentioned and contextualized in the next subsections), from which we have identified three key dimensions that have emerged as the most relevant in determining the final trajectories of such ULLs. All of them are deemed to play pivotal roles in unleashing the transformative potential of urban experimentation. In our framework, the latter are essential to identify both enablers that can lead to transformation as well as barriers that can cause death, marginalization, or assimilation of the experiments.

\subsubsection{Unconventionality}

Conventionality is the inclination of a public administration to adopt a classical pattern of action to achieve certain outcomes. It is closely linked to "path dependency", which was conceived as the propensity of public actors to reproduce past modes of actions through standard procedures, instead of proposing policy innovations [31]. In the urban context, this conventional approach is mainly based on the centralisation of power in urban planning and sustainable policies in the hands of a steady and proven governance. On the contrary, $\mathrm{CE}$ relies on the embracement of innovative tools by public actors to open up new perspectives in the reuse and redesign of products as well as the reduction of environmental impacts and the recycling of materials [32]. Therefore, transformative ULLs focused on CE should be based on unconventional procedures to break down the existing routines and enable urban actors to design, test, and learn from socio-technical innovations in real time [33]. They should involve citizens, grassroots associations, and start-ups through the use of new patterns of action in order to convey effective shifts. In our framework, unconventionality relies on the adoption of innovative contracts, new incentives or unusual procedures, designed by the public administration, to comply with circular experimentation.

\subsubsection{Autonomy}

The literature on urban governance has shown that, under certain conditions, communities can manage green areas and public spaces, as well as design basic physical and social infrastructures, and are capable of proposing innovative solutions [34,35]. According to this assumption, the aims of transformative ULLs are to create free places for experimental activities proposed by citizens, grassroots associations, and local companies. This aspect relies purely on the availability of the public administration to accept a certain degree of uncertainty and allow the empowerment of new actors, new roles for citizens as well as new groups of stakeholders [36]. The experimenters who have a high level of autonomy are allowed to create a living lab which responds to their creative necessities, with a strong perception of freedom in their range of actions. If cities wanted to guarantee autonomy, public offices would reduce bureaucratic barriers and the management of ULLs would be assigned directly to citizens, experimenters or external authorities [37]. Eventually, with a high level of autonomy, local municipalities would enable and preserve bottom-up initiatives to produce creative solutions and disrupting results. 


\subsubsection{Systemic Impact on Policies}

The systemic impact on policies entails shifts in established orders of urban governance as a result of the proposal of new actors, perspectives, and regulations in future policies. In the field of $\mathrm{CE}$, urban governance constantly needs to find flexible partnerships and to learn how to improve policies by testing new patterns of action through experiments [38,39]. According to McFadgen [40], the practice of governing cities can benefit from experiments if it constitutes a learning feedback loop between the experimental practices and the policy making arenas at other levels of scale. This learning includes assessing the public's response to new ideas, which can shape the policy agenda by pointing out clear results of a new policy solution. Although some urban experiments turned out to be effectively unconventional and autonomous, a large part of them risk being forgotten or limited to their small social circle [41]. In this framework, the systemic policy impact dimension concerns the presence of significant shifts in the ordinary long-term policies of CE. This entails the change of institutional structures and decision-making processes, as well as the establishment of new offices and administrative sections to support circularity.

\subsection{Methods of Research and Analysis}

Comparing cases of urban experimentation by means of most different systems design is considered a promising analytical approach to face policy issues [42]. This research method is based on the selection of a limited number of cases that have shown significant differences, in terms of timing, scale, and process, but seem to have taken a common path in addressing public problems [43]. MDSD is deemed to be particularly effective for capturing common patterns of change [44,45].

Amsterdam and Turin ULLs have been chosen among other cases after a final check with experts from the European Network of Living Labs (ENoLL). These two ULLs are highly comparable because of several common aspects: they encourage experimental CE activities proposed by individuals, associations, and companies to find new solutions to reintroduce materials and energy flows into the production cycle; both are aimed at regenerating former industrial areas that have suffered from the economic crisis and which are currently in need of conversion [46]; new forms of collaboration between citizens, private companies, and municipal governments are fostered [47,48].

At the same time, they also present significant differences that make the identification of common patterns of transformation particularly challenging. First, they are very different in timing: BSH started eleven years ago, while LLSC started two years ago. Started in 2009, BSH is an ongoing twenty-year circular transformation programme in Buiksloterham, a former industrial district that is currently undergoing a transition towards a mixed-used area with residential and re-manufacturing activities. LLSC was instead launched in 2018, and it has allowed eight companies to test circular processes for a period of up to nine months in different areas of the city. This difference might play a key role in the analysis of the systemic impact on policies: the different phases in which the two ULLs are located might provide useful indications on how governments can enable the transformation on an urban scale. From this viewpoint, LLSC could be considered as a control case to explore whether the same enablers and barriers which have determined the policy impact of BSH appear or not in a much younger ULL. Second, they take place at different scales: one district for BSH vs. different sites throughout the city for LLSC. At a first glance, the unconventionality would seem easier to reach from an ULL located in a single neighbourhood than another one spread in different areas of the city. This aspect might be particularly relevant to strengthen the research findings in the event that unconventional dynamics have generated common transformation patterns. Third, BSH was initiated thanks to a bottom-up initiative of a group of citizens interested in circular self-building, while LLSC was officially launched by the City of Turin as a regenerative project. This difference is relevant from the point of view of autonomy in order to consider the role of spontaneity in determining the activation of certain enablers and barriers.

The research methodology combined a review of the literature concerning urban experiments and ULLs in the two cities and fieldwork. Research papers and books related to BSH and LLSC and 
official reports and plans provided by the Amsterdam and Turin municipalities provided background information. Thirty-two semi-structured interviews (the semi-structured interviews were built on a standardized guideline and lasted between 40 and $90 \mathrm{~min}$, they were audiotaped with the interviewees' consent and fully reported in written form for further analysis) with 14 representatives of companies and associations (6 in Amsterdam and 8 in Turin), 6 civil servants (4 municipal managers in Amsterdam and 2 officials in Turin), 8 citizens ( 4 in Amsterdam and 4 in Turin), and 4 academic experts ( 1 from the University of Amsterdam, 1 from the Inholland Unversity of Applied Sciences, and 2 from the University of Turin) and participatory observation in twenty public events, workshops, and focus-groups held in Amsterdam and Turin between December 2018 and May 2020 provided the empirical pieces of evidence for the analysis.

\section{Circular Governance in Amsterdam and Turin}

In the last few decades, Amsterdam and Turin have begun to shape their governance by focusing on the issue of CE. Despite this common dynamic, these processes have taken place in a very different manner.

Far from being a fully worked out programme, the CE in Amsterdam functions as a narrative that "glues" a patchwork of urban projects, policies, and regulatory reforms that address the issue of resource efficiency. The origins of the CE policy discourse in Amsterdam can be traced back to the early debates on the efficiency of the waste and water utility sector in this city which took place back in 2009 [49]. The green-left government at that time devised implementation programmes for its newly edited strategic vision, documents that had the aim of combining economic development and sustainable urbanism (Structuurvisie Amsterdam 2040, structural vision Amsterdam). These early discussions on circularity ante-litteram considered the development and extension of the residual heating network and the stimulation of a "resource economy" (grondstoffeneconomie) that could boost urban economy during the darkest years of the real-estate downturn. In the early stages, circularity was addressed through a policy trajectory to trigger two transitions: one, towards smart logistics, hi-tech, green economy and biomass, and in particular through integrated energy systems; and the other towards a more decentralised "climate neutral" spatial development [50]. Today, Amsterdam's CE landscape is a heterogeneous network of policies, interventions, and projects, which is hard to define. The just published Amsterdam Circular Strategy 2020-2025 is the result of five years of experimentation in the city in all kinds of domains [51], ranging from decentralised and integrated water and waste infrastructures to the reuse of organic industrial and household waste for energy production, from the improvement of carbon neutral real-estate to the reuse of residual heat from the ever enlarging network of data storage facilities. Overall, from the early experiments of 2008-2010, the CE in Amsterdam has developed as a mainstream policy paradigm of green economic development and it is now presented as a unique approach to urban sustainability.

The Turin municipality approach has proved to be more controversial. In the last thirty years, Turin has been changing its identity due to the deep downturn of the local industrial sector. Starting from the end of '80s, an enduring governance has been proposed to find new solutions for the development, urban regeneration, and the recovery of former industrial spaces [52]. Despite the growth of tourism and the attractiveness of its universities, Turin is still struggling to achieve a new model of sustainable development. The main policies adopted within this framework to stimulate CE have concerned some local public services: paper, plastic, glass, and metal recycling; the use of energy produced by a waste-to-energy plant located on the edge of the city; the construction of a widespread district-heating network and the modernization of the water purification system. Some Green Public Procurement (GPP) rules have been introduced, although only in recent years, after directives for their use were issued at a national level in 2012, and, finally, with a law in 2015, which made GPP mandatory. CE policies in the water cycling, waste, energy, and gas sectors have been designed and implemented at the municipal level, as well as at the regional level, albeit mainly sectorially and not in an integrated way. Only recently have some of these policies been framed within a common framework that recalls 
CE concepts. The food policy and the management of Centro Agro Alimentare di Torino (CAAT) only begun to partially be reformed in order to fit some CE principles at the end of the 2010s, while initiatives to stimulate $\mathrm{CE}$ in the field of construction and building are still mostly left to the private sector, which often has to cope with strict regulations.

Regardless of the differences, $\mathrm{CE}$ is challenging the established "regime" of utility provision and urban development in both cities. The existing circular projects are at odds with the regulations and institutional architectures of utility provision, land governance, and development. Like many other cities in Europe, the material flows of Amsterdam and Turin are governed by a citywide infrastructure that has developed sartorially over the years. The waste, water, and energy utilities as well as the built environment are the main sectors affected by such a CE vision. The conventional path for urban development in Amsterdam and Turin has always been anchored in the capacity of public governments to build development coalitions between those players who have positional powers in the management of utility networks. The idea of CE started to indent this process, with more autonomous decentralised land and housing development programmes, off-grid housing and neighbourhood-based wastewater management (also used for underground heat/cool storage) and energy production (through local biogas stations, solar panels, and the like) processes. These initiatives require a different approach from the established urban development regime. The current initiatives are instead often organized around experimental initiatives of decentralised and more autonomous spatial development. The trajectories of the two cases are dissected in the following section, in order to assess their transformative potential.

\section{BSH: A Transformative Experiment at a City Level}

\subsection{Context}

Buiksloterham is a neighborhood in North Amsterdam (NDSM), which, for many years, was exclusively considered as a petrochemical and shipbuilding area. For the majority of Amsterdammers, NDSM was not a part of Amsterdam, and it had been defined as the "Siberia of Amsterdam" where nobody wanted to live [53]. With the increasing globalization, the Dutch naval sector experienced a decrease in profits and passed through a period of deep crisis between the '70s and '80s [54]. After a decade, due to the decline of the whole secondary sector, Amsterdam began to question the viability of earlier urban policy models and started to look for alternative ways of organically developing in NDSM [55]. In 2006, the North of Amsterdam officially became the subject of environmental and social regeneration: the municipality planned to invest 156 million euros in soil remediation, infrastructures, and means of transport. Furthermore, in order to better manage the renewal, the city's administration chose to cooperate with the NDSM district and funded a collaborative task body: Noordwaarts. This body had to handle the transformation of Buiksloterham into a sustainable mixed-used area of 2000 dwellings (30\% in the social-rental sector), $38,000 \mathrm{~m}^{2}$ of offices, and $25,000 \mathrm{~m}^{2}$ of cultural and community spaces. However, in 2008, the outbreak of the economic crisis shocked the whole private sector, including real estate and housing companies. The downfall affected the availability of public resources and led the municipality of Amsterdam to stop most of its public spending on urban renewals [56]. Among the projects that were stopped or held up was the regeneration plan of NDSM, and Buiksloterham consequently continued to be a former industrial area with no identity. The early experiments of CE came into being in a context of development uncertainty, in spite of the ample possibilities of testing alternative solutions and accommodating incoming development interests. Through a ULL based on the still in progress interaction between citizens, municipality and research institutes, the neighbourhood was gradually changing its model of development (Figure 1). 


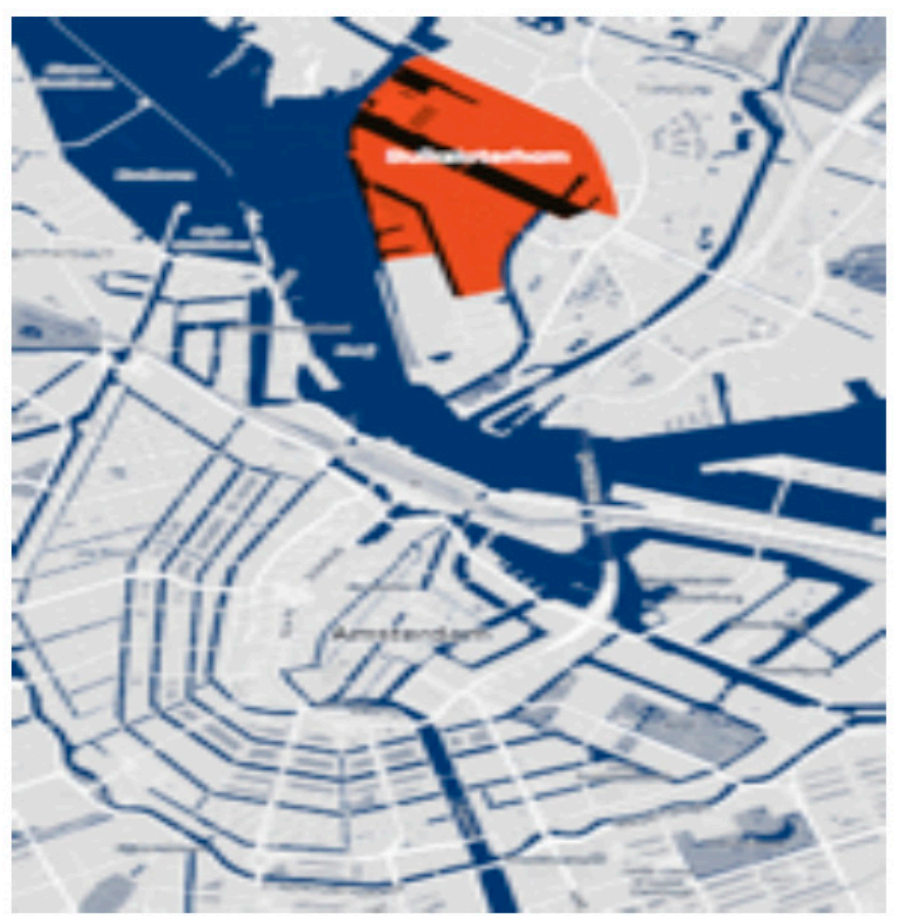

Figure 1. The location of Buiksloterham (www.dutchwatersector.com).

\subsection{Results}

\subsubsection{Unconventionality}

In Amsterdam, CE policies are usually linked to urban planning and energy resource management, on the basis of a consolidated partnership between the local government, multiutilities, and professional real-estate companies [57]. This standard pattern of action was suddenly challenged by the aforementioned crisis, which forced the municipality to look for unconventional ways of action. Between 2008 and 2009, when the downturn reached its peak, a spontaneous group of creative designers began to think about building in the unorthodox streets of Buiksloterham. They were attracted by the low location costs and proximity to the city centre, but even more so by the chance of becoming protagonists in the regeneration of former industrial spaces [58]. These pioneers wanted to structure their own houses from a circular perspective, by choosing reused materials and experimental energetic systems as well as self-sufficient heating. They came up with a two-fold opportunity to blend spatial regeneration with experimental self-building inspired by $\mathrm{CE}$, as one of them explained:

"During the crisis, no one wanted to build in Amsterdam (... ) Suddenly, there was a lot of energy from people who came up with the very good idea of sustainable floating houses. This was a bottom-up initiative boosted by people with a lot of expertise. Those pioneers were trying to put circularity to the top of the policy agenda." (I. 6)

The drift generated by the thriving community produced a tension between the established rules of urban planning —-namely the zoning plan and the environmental requirements-and the incoming demands for housing flexibility and new projects. Paradoxically, the self-builders' action turned out to be successful due to the economic crisis that was then gripping the real estate market, which was hampering the adoption of standard urban planning and regeneration policies [59]. The municipality of Amsterdam started to modify the land management and ground-lease dynamics, by off-settings funds and cost-recovery plans [60]. The municipality in Buiksloterham proposed reshaping the classical tool of "the building envelope procedure" — the assignation of maximum volumes to developers on the basis of tenders - to enable self-builders to realise their circular-building houses. For the first time, such contracts were based on Green Rated Points (GRP) to fix the minimal environmental requirements 
and to determine ad-hoc modulations of land prices. As explained by the interviewed civil servants, circular criteria had never been included in self-building procedures before those deals were set up. Those innovative agreements actually marked an alternative way of urban planning by boosting a building method that involved a much more "passive" role of the municipal offices and much more open framework rules. Since that moment, circular self-buildings became the identifying feature of Buiksloterham, which then started to be called BSH.

\subsubsection{Autonomy}

After these pioneering activities, BSH began to become appealing to a second wave of developers, mainly composed of young companies fascinated by aquaponics, urban-gardening, and waste recovery technologies. As shown by Heurkens [61], and revealed by the interviews, two tools drawn up by the municipality were decisive in consolidating the autonomy of the BSH Living Lab between 2012 and 2014: the opening of circular tenders and the temporary derogation of waste treatment. By relying on European urban regeneration funds, the municipality first decided to explore the possibility of developing a form of land concessions (gronduitgifte) bound to circular objectives [62]. To this end, the standard tool of public tendering was redesigned to contain evaluation criteria aimed at assessing experiments on material reuse, energy recovery, and the reduction of environmental impacts, as one civil servant explained:

"The first circular tender was made in 2012, when we introduced different aspects of circularity. The tender was normal, but the selection criteria were completely new. The selection of reused material was in particular a completely new aspect for us." (I.15)

The first circular tender enabled one of the main activities of the second wave, that is, De Ceuvel, an award-winning, sustainable planned workplace for creative and social enterprises, which obtained a ten-year ground lease to turn a former industrial site into a regenerative urban oasis. De Ceuvel has proposed many CE experiments, such as compost toilets, heat exchangers, helophytes, phytoremediation, and a blockchain system to optimise the management of energy offered by the Alliander company. Derogation became the key-action in this framework to unleash the inventiveness of the developers; De Ceuvel was able to rely on an exemption of regulations concerning the management and treatment of water waste, as one of its representatives stated:

"They gave us the opportunity to freely obtain land and avoid certain regulations. Moreover, we received a specific grant to start our activity because our initiative was assessed by the municipality as an incubator for circular economy development in the neighbourhood" (I.4)

In 2013, the second circular tender was made to support the building of Schoonship, which was located, by the Space and Matter architects' studio, in one of the main canals of BSH. It concerned a group of thirty floating insulated houseboats equipped with solar panels, green roofs and an innovative domestic water recovery system provided by the Waternet biorefinery company. Even in this case, exceptional waste and sewage recovery derogations allowed the ambient water to be harvested, cycled nutrients to be recovered and, finally, a unique circular experimentation site to be created.

The municipality enabled the second wave of developers to create their own experimental spaces in attractive spots, such as De Ceuvel (Figure 2) and Schoonschip, to set up certain rules and thereby enhance the local community [63]. Circular tenders and deregulation led BSH to gain its own autonomy and stand out from the other urban areas as a unique circular neighbourhood. 


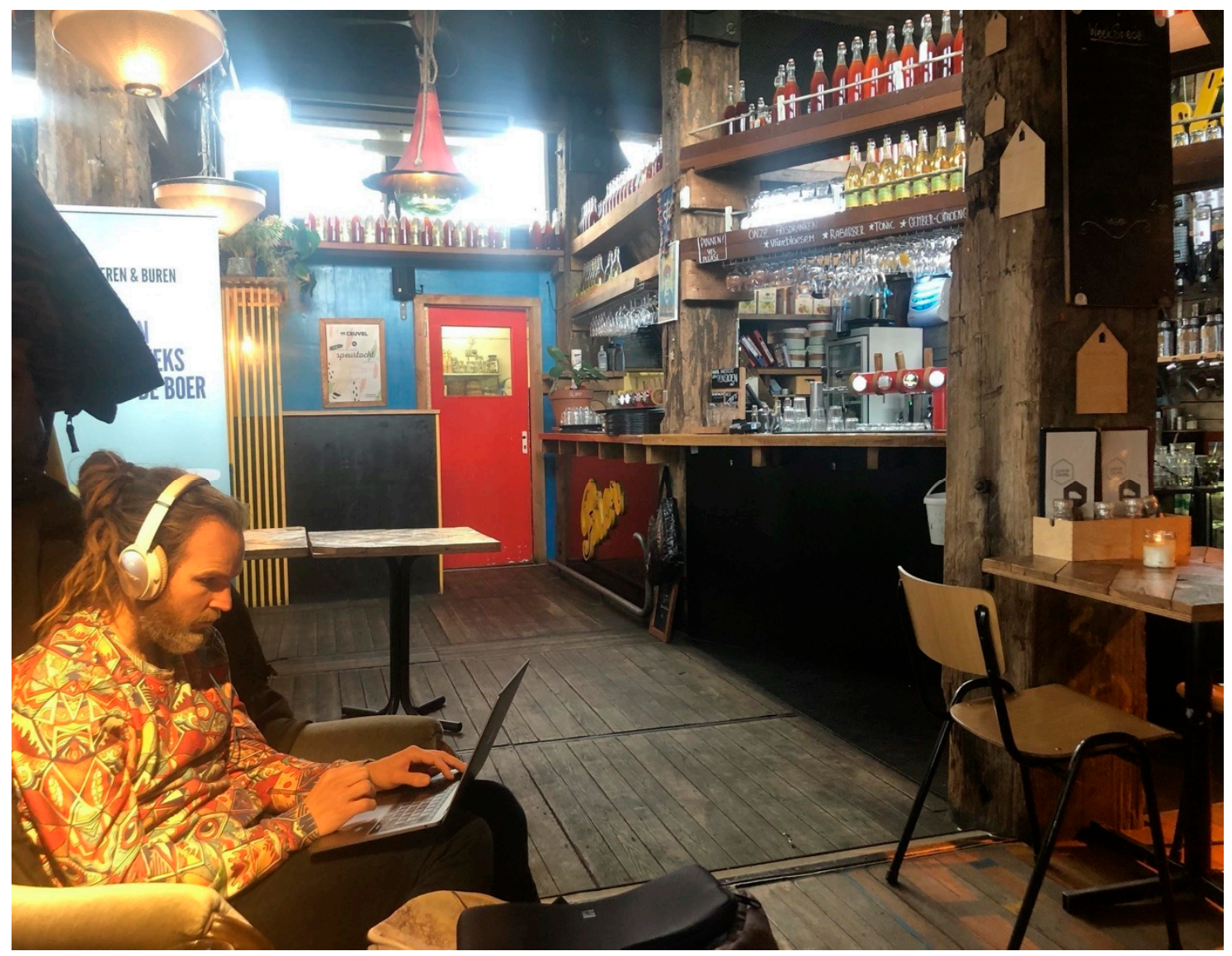

Figure 2. Cafe in De Ceuvel.

\subsubsection{Systemic Impact on Policies}

At the end of the crisis, the attractiveness of BSH began to increase on a larger scale for real-estate developments managed by commercial companies. The signing of the "BSH Manifesto" in 2015 marked the start of a formal partnership between twenty stakeholders: the municipality of Amsterdam, together with private companies, universities, and residents, committed themselves to the planning of a long-term transformation of the area, with a time horizon of 2034 [64]. After that deal, the local government began to re-develop BSH by opening the land allocation tenders to professional companies. Although circularity continued to formerly be considered at the top of BSH's agenda, the new development approach generated doubts and skepticism among the original pioneers, as one of them stated:

"Large traditional commercial companies have started to arrive in BSH. These belong to the old school's way of thinking industry. The Municipality depends on these kinds of companies to attract new investments and create jobs. The city has started to facilitate old-school companies which have nothing in common with sustainability and circularity." (I.1)

The ongoing densification of construction sites has also attracted criticism among the second-wave developers, who had previously believed in the opportunity of planning long-term systemic impacts through the signing of the manifesto, as explained by one De Ceuvel's representatives:

"Since the beginning, the bottom-up activities of CE have effectively been conducted together with the citizens. However, this has not produced any permanent transformation. Actually, the perspective has changed: land has to be sold and money has to be made." (I.4)

Despite the increasing skepticism of the first and second comers, the newcomers seem more hopeful of BSH's future. The Inholland University of Applied Sciences, Urban Leisure and Tourism 
Lab, which decided to propose university courses of designed-based programs in BSH in 2015, is one of the newcomers. Unlike first comers, they did not receive procedural financial facilities, but they are keen to be part of the dynamics going on in Buiksloterham. They look at BSH as a benchmark for future policies, including tourism:

"Buiksloterham is becoming an attractive new hub for a certain kind of tourist. The number of architects, researchers and developers who want to learn something from BSH is increasing. We need to understand how we can host them, while avoiding the overcrowding conditions of the city centre. This could represent a policy window to propose a new strategy of circular tourism." (I. 5)

Therefore, the systemic impact on urban policies is diversified. According to the interviewed municipal officials, BSH is a recognised benchmark of urban regeneration which has left an important mark on policies. Some BSH experiments stirred up the city's regulations on waste, such as the sewage recovery system tested in De Ceuvel, which has been certified and included in recent urban development plans [65]. Additionally, as reported by the municipality in the "Roadmap Circulaire Gronduitgifte" [66], BSH triggered the institution of a circular land concession system and several other projects in the city that have attempted to be more circular. The current Amsterdam Circular 2020-2025 strategy largely takes inspiration from the positive waste reuse practices that generated from this area. On the other hand, at the neighbourhood level, densification and real estate investments have taken over the circular self-building and the bottom-up experiments. Professional construction companies are currently proposing developments that, although still connected to the basic ideas of $\mathrm{CE}$, appear to bypass the more transformative ideas of circularity developed in the early phases of BSH (Figure 3).

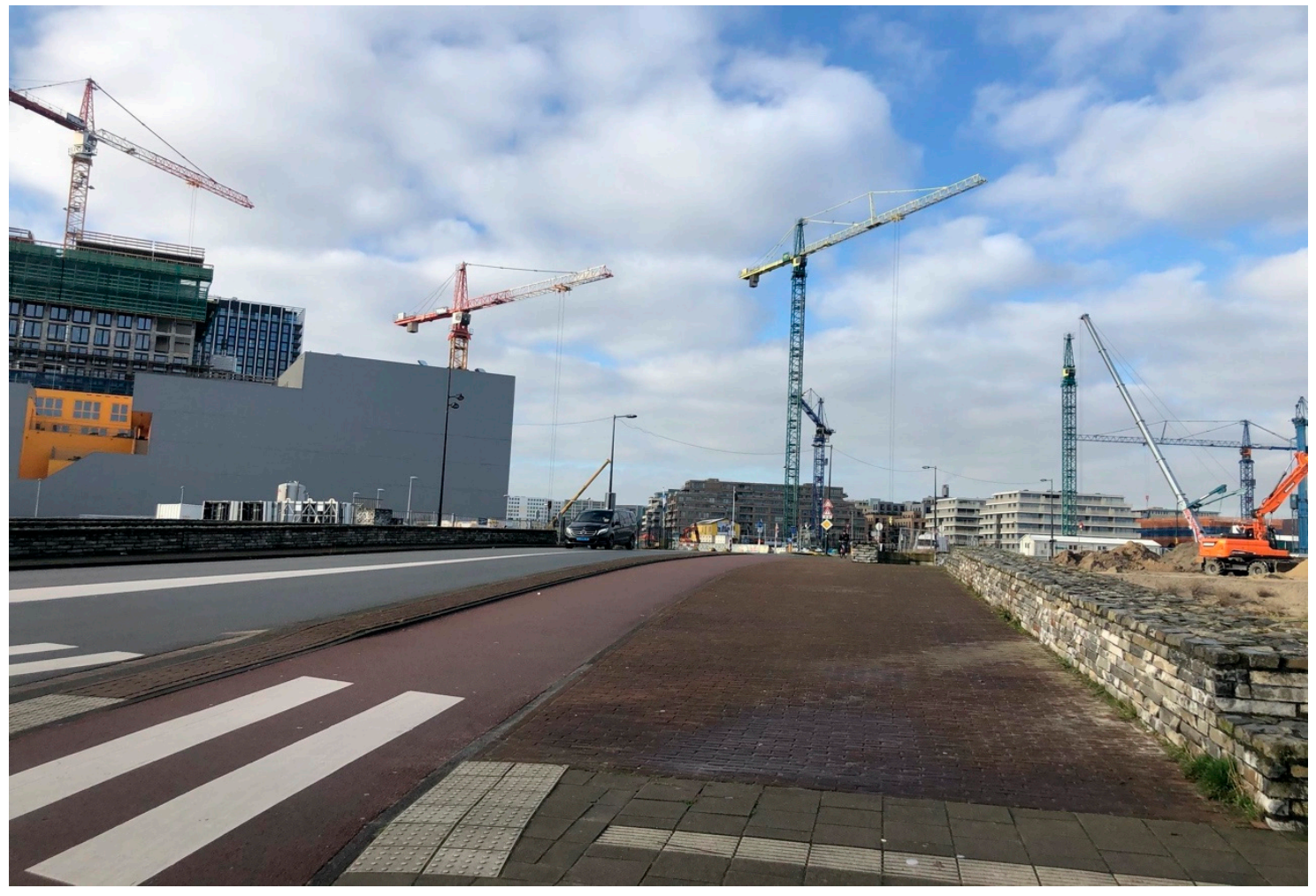

Figure 3. Building work in Buiksloterham.

\section{LLSC: A First Step towards Transformative Policies}

\subsection{Context}

LLSC was part of a wide urban regeneration programme, AxTo (Actions for the outskirts of Turin), which entailed forty-four initiatives aimed at reaching social and economic renewal of specific 
neighbourhoods. The municipality, relying on national funds made available by the Presidency of the Council of Ministers with the "Extraordinary intervention programme for urban regeneration and safety in the peripheries", decided to invest in five main fields: public spaces, housing, work and innovation, school and culture, and civic participation [67]. In the field of work and innovation, LLSC was designed by the municipal Innovation office to support $\mathrm{CE}$ activities and produce concrete environmental and social benefits for local communities. From May 2018 to December 2019, LLSC allowed CE companies and associations to test their circular solutions in public spaces by developing and improving them with the contribution of citizens. The call for experimental activities, which was opened in May 2018 and lasted until July 2018, made 100 thousand euros available to support the best proposals, with a maximum request of 15 thousand euros per proposal, that is, equal to $50 \%$ of the expected costs. In the meanwhile, the municipality spent 64 thousand euros on coaching and technical facilitation activities, provided by an external management authority. Finally, an ad-hoc evaluation committee ranked thirty one proposals and admitted the top eight, which entailed different flows of CE: (I) Beautiful Precious Plastic came up with a homemade plastic recycling system (Figure 4); (II) Edilizia Circolare restructured a cooperative with reused building materials; (III) Urbanaquafarm dealt with hydroponic cultivation techniques; (IV) RicuciTò recovered textile products; (V) Market Place tested an e-commerce platform designed for second-hand market operators; (VI) Abbasso Impatto proposed a new circular supply system for accommodation facilities; (VII) Suolo Sostitutivo experimented with regenerated soil; (VIII) Con il Cibo 2 recovered and redistributed food, by involving the homeless. Each of the projects was conducted in one of the different neighbourhoods selected for the renewal project, in this way involving citizens throughout the entire city. Through a regeneration initiative led by the municipality of Turin, a temporary ULL was built, relying on the fruitful collaboration between public administration, businesses, and citizens aimed at revitalizing the local economy in a circular way.

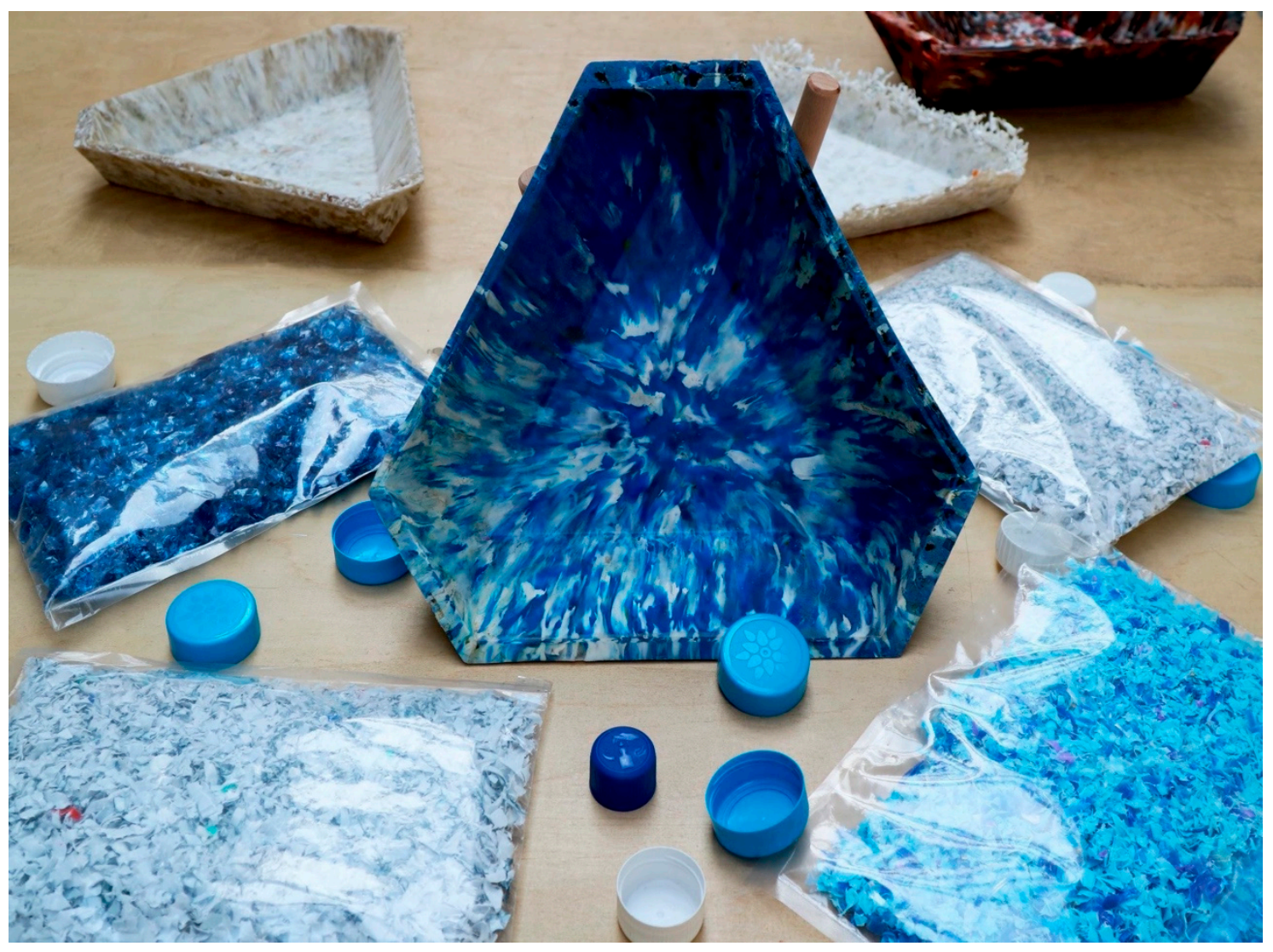

Figure 4. Homemade items in recycled plastic made by Beautiful Precious Plastic. 


\subsection{Results}

\subsubsection{Unconventionality}

The low propensity of public actors in Italy to act out of the box is a recognized and widely debated issue [68]. However, in spite of this, local governments seem to be more inclined to formulate unusual policies and propose urban experiments [69]. In LLSC, this aspect seems to have arisen at the top, through the approach adopted by the municipality of Turin, which came up with two unconventional tools: the experimental agreement and the evaluation commission.

In the previous decade, the municipality received many requests for circular experimentation in public spaces by local companies and associations. Although the public officials perceived the value of such proposals, they could not rely on suitable contracts, since ULLs did not then have a proper framework within the Italian regulatory system [70]. In order to face this gap, the municipal Innovation office decided to cooperate with legal experts from the University of Turin in order to enable circular experiments in a real-life context. After looking at healthcare trial deals, they came up with an "experimental agreement" to ensure transparency and comprehensiveness, which exceptionally allowed ad-hoc opportunities to be provided, as one municipal official stated:

"In the past, a lot of companies asked the municipality to test their sustainable products in real contexts. However, we did not have an appropriate contract to enable such initiatives (...) We have used an unusual contract, based on the clinical trial and university experiment model." (I.8)

The second unconventional tool emerged in the evaluation phase, when the municipality tested a new arena of decision. As a result of the heterogeneous contents of the circular proposals, the Innovation office on its own was not able to ensure comprehensive knowledge to evaluate different kinds of experimentation over a wide range of fields, such as agriculture, design, chemistry, and logistics. It was the multidimensionality of CE, rather than the experimental nature of LLSC, which was the key lever that led the municipality to think and act out of the box. For the first time, municipal offices decided to involve external experts and gather them around the same table in an attempt to improve the evaluation procedure. The evaluation committee identified five assessment criteria that could be used for the selection of proposals: technical feasibility, coherence, level of innovation, level of involvement, and economic sustainability. In stark contrast to the standard evaluations, based on closed meetings [71], these criteria represented a completely unusual tool of action and marked the take-off of LLSC.

\subsubsection{Autonomy}

Despite the municipality's attempt to ensure a certain degree of freedom for the experimenters, the autonomy of LLSC has been undermined by two main barriers: fragmentation in the management of public spaces and the strict Italian regulations concerning waste management. After analysing the past ULLs, the municipality assumed LLSC would need more autonomy, and this was ensured by involving a "management authority" with the aim of speeding up the authorizations and avoiding the piecemeal process that had hampered past experiences [72]. This led the management of LLSC to being moved to S\&T, a private society specialized in local development policies and community building. Nonetheless, this step turned out not to be sufficient to design free experimentation spaces and unleash disrupting activities. When S\&T tried to speed-up the bureaucratic process, the complex allocation of competencies between districts and municipality slowed-down the starting phase and consequently undermined the autonomy of the developers. For instance, as reported by an S\&T expert, it was not possible to conduct certain hydroponics experiments, as some of the more promising cultivations could no longer be conducted, due to long delays in the space concessions.

In addition to the piecemeal authorizations, some of the developers also had to deal with Italian waste recovery regulations, which imply restrictive and complex requirements, especially in the recovery of building materials and the reuse of plastics [73]. Among these developers, Suolo Sostitutivo 
had to rearrange their initial plan to test regenerated soil. The experimentation of this circular product, a blend of compost and waste materials from the building sector, would have involved urban gardening associations assessing the potential of the product for agricultural purposes in public spaces. However, the huge number of unavoidable authorizations eventually led them to conduct the test in laboratories, as one civil servant stated:

"No particular autonomy had been granted. The number of permissions related to testing of real-life context circular products was too large and complex. As a result, the regenerated soil was finally tested in a laboratory." (I. 9)

As claimed by all the developers, these two regulatory hurdles seemed to have seriously undermined the autonomy of LLSC. They slowed down the testing phase by weakening their capacity of involvement and the territorial impact. Furthermore, they prevented activities that needed specific derogations from being tested beyond the current waste management regulations. For these reasons, LLSC failed to create autonomous and disrupting spaces for CE experiments.

\subsubsection{Systemic Impact on Policies}

Since the experiments have ended, the municipality has announced its intention to design long-term CE policies, starting from the LLSC results [74]. It has in fact been working on creating an internal office to help circular companies obtain new financial resources and collaboration opportunities. From the municipal officials' perspective, this "hub" could represent a stable landmark to boost circular activities. However, according to the vast majority of the interviewees, the systemic impact on policies is uncertain and controversial. On the one hand, as pointed out by the Urbanaquafarm developers, who worked with urban gardening associations, LLSC seems to have laid the groundwork for future circular policies by creating new networks of circular developers:

"After LLSC, all the partners that were involved are keen to turn the project into a steady experimentation of hydroponic and aquaponic crops and to provide guidelines for local horticulturists. The project partners will also activate all the efforts and initiatives that may be useful to find the financial resources to expand the intervention area." (I.18)

In the same way, after nine months of experimentation inside LLSC, Marketplace built up a new network, which was transformed into a permanent e-commerce platform, aimed at bridging operators and purchasers involved in the second-hand market [75]. However, there is skepticism about the opportunity of shaping concrete policies. The RicuciTò developers, who conducted laboratories with design students and prison inmates to turn textile waste into new slippers, kitchen pot holders, and wardrobe perfume makers, admitted to being more cautious about the future of LLSC, and stressed the lack of permanent public support for circular activities. Although this necessity was mentioned by all of the developers, no formal action has been formalized as yet. As one of the municipal officials stated, the lack of cooperation between different municipality offices is actually affecting the systemic impact of LLSC:

"An urban policy of circular economy requires different branches of the municipality to work together. Until now, the difficulty municipal offices have shown in collaborating has been a deterrent to achieving an effective policy impact. At the moment, LLSC continues to be stuck at a temporary experimentation stage." (I.8)

These inner conflicts seem to be hampering the setting up of the hypothetical hub. Hence, the new networks of companies, associations, and citizens sensitive to the issue of CE may run the risk of not finding any concrete outlets on the political agenda. These opposing dynamics have made a comprehensive analysis of the systemic impact of LLSC uncertain. 


\section{Discussion}

Moving from the wide debate on urban experimentation, we have pointed out how transformation can take place by means of very different configurations of ULLs. In accordance with the literature cited in paragraphs 1 and 2.1, both the selected cases have triggered co-productive processes capable of transforming an entire urban area into a circular neighbourhood or underpinning new circular activities in post-industrial peripheries. However, the path of the ULLs under examination has proven to be neither linear nor easily comprehensible without specific analytical lenses. Many factors have affected their trajectories and have determined irregular transformative results.

By tracing the paths of BSH and LLSC back through three analytical dimensions, we can highlight the main enablers and barriers that had an impact on their trajectories.

Both labs were developed and built around the use of unconventional policy tools and approaches. BSH explicitly distanced itself from the public-led development model already established in the city. Circular self-building proposals led the Amsterdam municipality to adapt frameworks and make space for innovative ways of developing land, such as the adoption of self-building procedures and the use of circular procurement rules in the area. LLSC was instead launched by the city's local government itself, with the two-fold aim of regenerating neighbourhoods and providing opportunities for circular companies. Even though LLSC was clearly headed by the municipality, it adopted an unconventional approach to CE. By means of the experimental partnership agreement it enabled an experimentation process in specific territorial contexts to take place. Moreover, the heterogeneity of the evaluation committee turned out to be an unconventional and effective setup for an open arena of decisions.

The nature of the autonomy adopted in the two cases shows clear differences. BSH succeeded in creating its own regulatory space through two main enablers. Firstly, circular tenders enabled practitioners to create community hubs focused on circular experimentation. Secondly, derogation in waste management allowed innovative and decentralised waste recovery systems to be proposed. Conversely, LLSC failed to guarantee autonomy to its experimenters, due to the piecemeal management of public spaces and the mandatoriness of the waste regulations. This difference may be due to the limited possibility of Italian municipalities of avoiding or adapting laws of national competence.

Despite the very different "ages", both cases seem to have had an initial impact on policies, but this impact has taken multiple forms and scales, and it is not unitary or direct. The lab in Amsterdam was benchmarked as a circular redevelopment model at an urban scale and it inspired many of the circularity policy frameworks in the city. However, although its impact at the city scale was evident, the legacy of the area shows a very different feature. It has been assimilated by the standard logic of the real-estate market in Buiksloterham, with little remaining of the more unconventional experiments of its early phases. LLSC, a much younger project, is also showing diverging dynamics. On the one hand, it has created new networks of circular developers and has increased the attention of policymakers to $C E$. On the other, its influence on concrete long-term policies is not yet visible and the municipality has not yet undertaken substantial or visible initiatives to upscale the project. Although the lab may have more of an impact at later stages, the current policy developments around LLSC suggest that such a non-cooperative approach within the municipality could undermine its transformative potential by locking-in its systemic impact on policies.

This evidence shows that the trajectories of laboratories are multi-scalar and non-linear. BSH has taken a two-fold direction. At the local level, the lab has de facto been assimilated and has gradually lost its circular and disruptive identity. Nonetheless, its transformative potential has unfolded at other levels of scale. The project has triggered a series of circular policies at a city level. The first phase of the Turin LLSC has just ended and it is now facing an uncertain future. The extent to which it will preserve or enact its transformative potential remains a question. However, the recent developments suggest that it will incur the risk of marginalization [76]. Its future still appears uncertain, but it is closely linked to the municipality's ability to overcome inner conflicts in order to create opportunities for circular developers (Table 1). 
Table 1. Drivers of the Buiksloterham Living Lab (BSH) and Living Lab on Sharing and Circular (LLSC) dimensions (upward arrows $(\uparrow)$ mean enablers with positive effects on the corresponding dimensions, while the downward arrows $(\downarrow)$ point out barriers with negative impacts on the dimensions).

\begin{tabular}{|c|c|c|c|}
\hline ULL & Unconventionality & Autonomy & Systemic Impact \\
\hline BSH & $\begin{array}{c}\uparrow \text { Circular self-building } \\
\uparrow \text { Building envelope } \\
\text { procedures }\end{array}$ & $\begin{array}{c}\uparrow \text { Circular tenders } \\
\uparrow \text { Waste management } \\
\text { derogations }\end{array}$ & $\begin{array}{l}\downarrow \text { Standard logic of the } \\
\text { real-estate market } \\
\uparrow \text { Circular regeneration } \\
\text { benchmark }\end{array}$ \\
\hline LLSC & $\begin{array}{l}\uparrow \text { Partnership agreement } \\
\uparrow \text { Heterogeneity of the } \\
\text { evaluation committee }\end{array}$ & $\begin{array}{l}\downarrow \text { Piecemeal management of } \\
\text { public spaces } \\
\downarrow \text { Mandatoriness of the } \\
\text { waste regulation procedures }\end{array}$ & $\begin{array}{c}\uparrow \text { Networks of circular } \\
\text { developers } \\
\downarrow \text { Non-cooperation between } \\
\text { municipal offices }\end{array}$ \\
\hline
\end{tabular}

\section{Conclusions}

In their efforts to enable a transition towards a circular economy, cities are embracing ULLs as tools that can be used to trigger innovative policies and practices concerning the reuse of materials and the integration of material streams. This paper has dissected the paths and trajectories of two of these ULLs and shows the need to look at the set up and evolution of living labs over time. This is necessary to understand the underlying factors that lead them to preserve or dissipate their transformative potential. Two main clues have emerged, in terms of content and analytical approach for future research. First, the analysis of BSH and LLSC has pointed out how enablers and barriers may determine controversial trajectories with results that differ according to the dimension and the scale of reference. BSH, with its high level of unconventionality and autonomy, produced a transformative impact at the urban scale, but it was locally assimilated once the real-estate market had recovered from the global financial crisis of 2008. LLSC, instead, entailed an unusual approach to boost regeneration and circular activities, which could be useful to design long-term transformation. However, it neither created autonomous experiment spaces nor achieved any concrete impacts on policies.

Both ULLs have proven to be processes and arenas capable of enabling unconventional approaches and having a positive - even if controversial—systemic impact on policies. On the contrary, the opposite dynamics that have occurred in terms of autonomy suggest that spontaneously born ULLs (as the case of BSH) can guarantee more freedom of experimentation than those organised by public institutions (as the case of LLSC). Although two case studies have provided a narrow perspective to draw reliable findings, this aspect may offer interesting insights for future comparative research.

Second, this paper shows that the focus on the three dimensions of unconventionality, autonomy, and systemic impact on policies can offer a practical framework that may be adopted to develop a multi-scalar and time-sensitive comparison and assessment of the transformative potential of urban experiments. These dimensions can be used to analyse which factors influence the development of innovative experiments, why some experiments die, why others are marginalized, assimilated, or transformed. and to explain the reasons for their trajectories. Once again, even if our work has had the limitation of using these comparative lenses to analyse only two very different case studies, it might open future avenues of research to devise more consistent insights into the key factors that preserve the transformative potential of ULLs. Future researches could be focused on how to guarantee unconventionality, autonomy, and a systemic impact on policies. This next step could provide helpful and practical results for both those policymakers and policy designers who are interested in formulating transformative ULLs for a circular economy. At the same time, it could open up new challenging scenarios for urban study and public policy scholars.

Author Contributions: Conceptualization, S.R.; formal analysis, F.S.; methodology, L.B.; writing—original draft, F.C. All authors have read and agree to the published version of the manuscript.

Funding: This research received no external funding. 
Acknowledgments: We would like to thank the scholars of the Innovation for the economy PhD course of the University of Turin, and the Urban Planning research group of the University of Amsterdam for their detailed comments and suggestions on the manuscript.

Conflicts of Interest: The authors declare no conflict of interest.

\section{References}

1. Baccarne, B.; Logghe, S.; Schuurman, D.; De Marez, L. Governing quintuple helix innovation: Urban living labs and socio-ecological entrepreneurship. Technol. Innov. Manag. Rev. 2016, 6, 22-30. [CrossRef]

2. Ellen Macharthur Foundation. Circular Economy in Cities: Project Guide 2019. Available online: https: //www.ellenmacarthurfoundation.org/publications/circular-economy-in-cities-project-guide (accessed on 16 March 2020).

3. Girard, L.F.; Nocca, F. Moving towards the circular economy/city model: Which tools for operationalizing this model? Sustainability 2019, 11, 6253. [CrossRef]

4. Frantzeskaki, N.; Van Steenbergen, F.; Stedman, R.C. Sense of place and experimentation in urban transitions: The Resilience Lab in Carnisse, Rotterdam, The Netherland. Sustain. Sci. 2018, 13, 1045-1059. [CrossRef] [PubMed]

5. McCormick, K.; Anderberg, S.; Coenen, L.; Neij, L. Advancing sustainable urban transformation. J. Clean. Prod. 2013, 50, 1-11. [CrossRef]

6. Von Wirth, T.; Fuenfschilling, L.; Frantzeskaki, N.; Coenen, L. Impacts of urban living labs on sustainability transitions: Mechanisms and strategies for systemic change through experimentation. Eur. Plan. Stud. 2018, 27, 229-257. [CrossRef]

7. Bergvall-Kåreborn, B.; Ihlström Eriksson, C.; Ståhlbröst, A. Places and spaces within living labs. Technol. Innov. Manag. Rev. 2015, 5, 37-47. [CrossRef]

8. Wolfram, M. Cities shaping grassroots niches for sustainability transitions: Conceptual reflections and an exploratory case study. J. Clean. Prod. 2018, 173, 11-23. [CrossRef]

9. Chroneer, D.; Stahlbrost, A.; Habibipour, A. Urban living labs: Towards an integrated understanding of their key components. Technol. Innov. Manag. Rev. 2019, 9, 50-62. [CrossRef]

10. Baccarne, B.; Mechant, P.; Schuurman, D. Empowered cities? An analysis of the structure and generated value of the smart City. In Smart City-How to Create Public and Economic Value with High Technology in Urban Space; Dameri, R.P., Rosenthal-Sabroux, C., Eds.; Springer International Publishing: Cham, Switzerland, 2014.

11. Leminen, S.; Westerlund, M.; Nyström, A.G. Living labs as open innovation networks. Technol. Innov. Manag. Rev. 2012, 2, 6-11. [CrossRef]

12. Voytenko, Y.; McCormick, K.; Evans, J.; Schliwa, G. Urban living labs for sustainability and low carbon cities in Europe: Towards a research agenda. J. Clean. Prod. 2016, 123, 45-54. [CrossRef]

13. Evans, J.; Karvonen, A. “Give me a laboratory and I will lower your carbon footprint!" Urban laboratories and the governance of low-carbon futures. Int. J. Urban. Reg. Res. 2014, 38, 413-430.

14. Buhr, K.; Federley, M.; Karlsson, A. Urban living labs in suburbs in need of modernization and social uplift. Technol. Innov. Manag. Rev. 2017, 6, 27-34.

15. Huitema, D.; Jordan, A.; Munaretto, S.; Hildén, M. Policy experimentation: Core concepts, political dynamics, governance and impacts. Policy Sci. 2018, 51, 143-159. [CrossRef] [PubMed]

16. Truffer, B.; Murphy, J.T.; Raven, R. The geography of sustainability transitions: Contours of an emerging theme. Environ. Innov. Soc. Transitions 2015, 17, 63-72. [CrossRef]

17. Gerritsen, M.; Savini, F.; Revilla, B.P. The social appraisal of techno-experiments: Whirlpools and mosaics of smart urbanism. J. Urban. Technol. 2020, 27, 1-22. [CrossRef]

18. Ballon, P.; Van Hoed, M.; Schuurman, D. The effectiveness of involving users in digital innovation: Measuring the impact of living labs. Telemat. Inform. 2018, 35, 1201-1214. [CrossRef]

19. Savini, F. Responsibility, polity, value: The (un)changing norms of planning practices. Plan. Theory 2018, 18, 58-81. [CrossRef]

20. Pesch, U. Tracing discursive space: Agency and change in sustainability transitions. Technol. Forecast. Soc. Chang. 2015, 90, 379-388. [CrossRef]

21. Raven, R.; Sengers, F.; Spaeth, P.; Xie, L.; Cheshmehzangi, A.; De Jong, M. Urban experimentation and institutional arrangements. Eur. Plan. Stud. 2019, 27, 258-281. [CrossRef] 
22. Marvin, S.; Bulkeley, H.; Mai, L.; McCormick, K.; Palgan, V.Y. Urban Living Labs. Experimenting with City Futures, 1st ed.; Routledge: London, UK, 2018.

23. Savini, F.; Bertolini, L. Urban experimentation as a politics of niches. Environ. Plan. A Econ. Space 2019, 51, 831-848. [CrossRef]

24. Williams, J. Lost in translation: Translating low carbon experiments into new spatial contexts viewed through the mobile-transitions lens. J. Clean. Prod. 2017, 169, 191-203. [CrossRef]

25. Avelino, F.; Grin, J.; Pel, B.; Jhagroe, S. The politics of sustainability transitions. J. Environ. Policy Plan. 2016, 18, 557-567. [CrossRef]

26. Bulkeley, H.; Marvin, S.; Palgan, Y.V.; McCormick, K.; Breitfuss-Loidl, M.; Mai, L.; Von Wirth, T.; Frantzeskaki, N. Urban living laboratories: Conducting the experimental city? Eur. Urban. Reg. Stud. 2018, 26, 317-335. [CrossRef]

27. Schliwa, S.; Evans, J.; McCormick, K.; Voytenko, Y. Living labs and sustainability transitions-Assessing the impact of urban experimentation. In Proceedings of the INOGOV Workshop: Climate Change Policy and Governance: Initiation, Experimentation, Evaluation Helsinki, Finland, 12-13 March 2015.

28. Gaede, J.; Meadowcroft, J. A Question of Authenticity: Status quo bias and the international energy agency's world energy outlook. J. Environ. Policy Plan. 2015, 10, 608-627. [CrossRef]

29. Dembski, S. Case Study Amsterdam Buiksloterham, The Netherlands: The Challenge of Planning Organic Transformation; CONTEXT Report 2; AISSR Programme Group Urban Planning: Amsterdam, The Netherlands, 2013.

30. Bouw, M.; Thoma, D. Economic resilience through community-driven (real estate) development in Amsterdam-Noord. In The Hackable City; de Lange, M., de Waal, M., Eds.; Springer Science and Business Media LLC: Singapore, 2018; pp. 119-127.

31. Peters, B.G.; Pierre, J.; King, D.S. The politics of path dependency: Political conflict in historical institutionalism. J. Politics 2005, 67, 1275-1300. [CrossRef]

32. Nohra, C.G.; Pereno, A.; Barbero, S. Systemic design for policy-making: Towards the next circular regions. Sustainability 2020, 12, 4494. [CrossRef]

33. Markard, J.; Raven, R.; Truffer, B. Sustainability transitions: An emerging field of research and its prospects. Res. Policy 2012, 41, 955-967. [CrossRef]

34. Hordijk, M.A. Of Dreams and Deeds: The Role of Local Initiatives for Community Based Environmental Management in Lima, Peru. Ph.D. Thesis, University of Amsterdam, Amsterdam, The Netherlands.

35. Hoffman, J. Theorizing power in transition studies: The role of creativity and novel practices in structural change. Policy Sci. 2013, 46, 257-275. [CrossRef]

36. Mukhtar-Landgren, D.; Smith, G. Perceived action spaces for public actors in the development of Mobility as a Service. Eur. Transp. Res. Rev. 2019, 11, 32. [CrossRef]

37. Kronsell, A.; Mukhtar-Landgren, D. Experimental governance: The role of municipalities in urban living labs. Eur. Plan. Stud. 2018, 26, 988-1007. [CrossRef]

38. Da Cruz, N.; Rode, P.; McQuarrie, M. New urban governance: A review of current themes and future priorities. J. Urban. Aff. 2019, 41,1-19. [CrossRef]

39. Glaser, M.; Brömmelstroet, M.T.; Bertolini, L. Learning to build strategic capacity for transportation policy change: An interdisciplinary exploration. Transp. Res. Interdiscip. Perspect. 2019, 1, 100006. [CrossRef]

40. McFadgen, B.; Huitema, D. Stimulating learning through policy experimentation: A multi-case analysis of how design influences policy learning outcomes in experiments for climate adaptation. Water 2017, 9, 648. [CrossRef]

41. Jurgilevich, A.; Birge, T.; Kentala-Lehtonen, J.; Korhonen-Kurki, K.; Pietikäinen, J.; Saikku, L.; Schösler, H. Transition towards circular economy in the food system. Sustainability 2016, 8, 69. [CrossRef]

42. Ward, K. Editorial-Toward a comparative (re)turn in urban studies? Some reflections. Urban. Geogr. 2008, 29, 405-410. [CrossRef]

43. Krehl, A.; Weck, S. Doing comparative case study research in urban and regional studies: What can be learnt from practice? Eur. Plan. Stud. 2020, 28, 1-19. [CrossRef]

44. Anckar, C. On the applicability of the most similar systems design and the most different systems design in comparative research. Int. J. Soc. Res. Methodol. 2008, 11, 389-401. [CrossRef]

45. Gerring, J. Case Study Research: Principles and Practices, 1st ed.; Cambridge University Press: Cambridge, UK, 2006.

46. Ostrom, E. Governing the Commons, 1st ed.; Cambridge University Press: Cambridge, MA, USA, 1990. 
47. Evans, J.; Karvonen, A.; Raven, R. The experimental city. In The Experimental City; Routledge: London, UK, 2016; pp. 1-12.

48. Moore, M.L.; Olsson, P.; Nilsson, W.; Rose, L.; Westley, F.R. Navigating emergence and system reflexivity as key transformative capacities: Experiences from a Global Fellowship program. Ecol. Soc. 2018, 23, 38. [CrossRef]

49. Savini, F. The economy that runs on waste: Accumulation in the circular city. J. Environ. Policy Plan. 2019, 21, 675-691. [CrossRef]

50. Markus, M.; Savini, F. The implementation deficits of adaptation and mitigation: Green buildings and water security in Amsterdam and Boston. Plan. Theory Pract. 2016, 17, 497-515. [CrossRef]

51. City of Amsterdam. Amsterdam Circular 2020-2025 Strategy. 2020. Available online: https://www.amsterdam. nl/en/policy/sustainability/circular-economy/ (accessed on 6 February 2020).

52. Belligni, S.; Ravazzi, S. La Politica e la Città. Regime Urbano e Classe Dirigente a Torino, 1st ed.; Il Mulino: Bologna, Italy, 2012.

53. Savini, F.; Dembski, S. Manufacturing the creative city: Symbols and politics of Amsterdam North. Cities 2016, 55, 139-147. [CrossRef]

54. Wilschut, M.; Theuws, P.; Duchhart, I. Phytoremediative urban design: Transforming a derelict and polluted harbour area into a green and productive neighbourhood. Environ. Pollut. 2013, 183, 81-88. [CrossRef] [PubMed]

55. Savini, F. Political dilemmas in peripheral development: Investment, regulation, and interventions in metropolitan Amsterdam. Plan. Theory Pract. 2013, 14, 333-348. [CrossRef]

56. Van de Klundert, F. Economic Resilience at Buiksloterham. Available online: http://thehackablecity.nl/2016/ 04/11/economic-resilience-at-buiksloterham/ (accessed on 2 December 2019).

57. De Langen, P.; Sornn-Friese, H.; Hallworth, J. The role of port development companies in transitioning the port business ecosystem: The case of port of amsterdam's circular activities. Sustainability 2020, 12, 4397. [CrossRef]

58. Revilla, B.; Savini, F. Unpacking energy needs. Framing decency in Amsterdam communities. In From Efficiency to Reduction; Savini, F., Revilla, B., Pfeffer, K., Bertolini, L., Eds.; In Planning: Amsterdam, The Netherlands, 2019.

59. Reimerink, L. How Amsterdam Turned a Polluted Industrial Site Into its Most Interesting Neighborhood; Eco-Business: Singapore, 2016.

60. Savini, F. Planning, uncertainty and risk: The neoliberal logics of Amsterdam urbanism. Environ. Plan. A Econ. Space 2017, 49, 857-875. [CrossRef]

61. Heurkens, E. Sustainable urban development in The Netherlands. In Handbook of Sustainable Real Estate; Routledge: London, UK, 2018.

62. OECD. Public Value in Public Service Transformation: Working with Change. Available online: https: //www.oecd.org/governance/public-value-in-public-service-transformation-47c17892-en.htm (accessed on 7 May 2020).

63. Bouw, M. This Tiny Amsterdam Neighborhood Is a Prototype for Grassroots Urban Planning. Available online: https:/www.metropolismag.com/cities/buiksloterham-amsterdam-grassroots-planning/ (accessed on 24 January 2020).

64. Gladek, E.; Van Odijk, S.; Theuws, P.; Herder, A. Transitioning Amsterdam to a Circular City: Circular Buiksloterham; Metabolic, Studioninedots \& DELVA Landscape Architects: Amsterdam, The Netherlands, 2015.

65. City of Amsterdam. Investeringsnota Buiksloterham 2019. Available online: https://www.amsterdam.nl/ projecten/buiksloterham/plan-publ-buiksl/samenvatting-investeringsnota/ (accessed on 6 February 2020).

66. City of Amsterdam. towards the Amsterdam Circular Economy. Available online: https://assets.amsterdam. nl//towards_the_amsterdam_circular_economy_web.pdf (accessed on 14 February 2020).

67. City of Turin. AxTO: Relazione Generale. Available online: http://www.comune.torino.it/arredourbano/bm \{\}doc/relazione-generale-axto.pdf (accessed on 15 April 2020).

68. De Masi, D. Lo Stato Necessario, 1st ed.; Rizzoli: Segrate, Italy, 2020.

69. Mareggi, M. Innovation in urban policy: The experience of italian urban time policies. Plan. Theory Pract. 2001, 3, 173-194. [CrossRef]

70. Paoni, S.; Massoli, A.; Tudisco, V. Living Lab; Network: Perugia, Italy, 2017. 
71. Nesti, G. Co-production for innovation: The urban living lab experience. Policy Soc. 2018, 37, $310-325$. [CrossRef]

72. Profeti, S.; Tarditi, V. Le pratiche collaborative per la co-produzione di beni e servizi: Quale ruolo per gli enti locali? In Proceedings of the Conference Paper SISP, Lecce, Italy, 12-14 September 2019.

73. Mariotti, N.; Ascione, G.S.; Cottafava, D.; Cuomo, F. Critical barriers for plastic recycling. Procedia Environ. Sci. Eng. Manag. 2019, 6, 169-180.

74. Metropolitan City of Turin. GPP, Green Economy, Green Education. Available online: http://www. cittametropolitana.torino.it/cms/ambiente/green-economy-education (accessed on 20 February 2020).

75. TorinoClick. Il Balon è AxTO ma su Internet Nasce il Marketplace 1solo.com. Available online: http: //www.torinoclick.it/?p=88670 (accessed on 28 April 2020).

76. SocialFare. Torino Living Lab AxTO 3.02. Available online: https://socialfare.org/impact-design/ torinolivinglab/ (accessed on 18 January 2020).

(C) 2020 by the authors. Licensee MDPI, Basel, Switzerland. This article is an open access article distributed under the terms and conditions of the Creative Commons Attribution (CC BY) license (http://creativecommons.org/licenses/by/4.0/). 